GLOBAL JOURNAL OF AGRICULTURAL SCIENCES VOL. 17, 2018: 23-31

COPYRIGHT@ BACHUDO SCIENCE CO. LTD PRINTED IN NIGERIA ISSN 1596-2903 www.globaljournalseries.com, Email: info@globaljournalseries.com

\title{
COSTS AND RETURN ANALYSIS OF FISH FARMING IN CALABAR METROPOLIS, CROSS RIVER STATE NIGERIA
}

\author{
E. O. EDET, P. O. UDOE, E. D. UWAH \\ (Received $5^{\text {th }}$ May 2016; Revision Accepted 25 June 2018)
}

\begin{abstract}
The study examines the costs and returns analysis of fish farming in Calabar Metropolis, Cross River State. A twostage sampling technique was used to select 30 fish farmers from two local government areas in the Calabar metropolis. Data for the study were sourced via structured questionnaire and were analyzed using descriptive and inferential statistics alongside budgetary techniques. Results showed that more men (70\%) were involved in fish farming and that $33 \%$ were between the age brackets of $40-49$ years, operating majorly $(56,70 \%)$ on small scale basis with $40 \%$ of them having a family size of $2-4$ persons and most $(83.3 \%)$ being literates. The results of the budgetary analysis show that average total cost (TC) of $\$ 525,000$ was incurred and total revenue (TR) of $\$ 650,000$ was realized giving a returning gross margin (GM) of $\$ 425,000$ with a Net farm income (NFI) of $\$ 125,000$ per cycle. This is an indication that fish farming is profitable in the study area using a minimum of 1000 fingerlings for a start. From the results, feeds cost, production systems, education level and stocking density were important factors that influence fish output. Constraints perceived by most of the farmers include: high cost of fish feeds, lack of awareness and skilled personnel were identified $a b$ initio that hindered fish production in the area. The study, therefore, recommended that the development of nutritive research institute for the development of fish feeds is a sine qua none for enhanced productivity in the fishery subsector in Nigeria.
\end{abstract}

KEYWORDS: Fish farming, fingerlings, returns, revenue, total cost

\section{INTRODUCTION}

Fish farming is one of the fastest-growing animal based food production sector, particularly in the developing countries (Green facts, 2004). In Africa, the fish sector provides income for over 10 million people engaged in fish production, processing and trade (New Partnership for African Development, 2005). Fish has also become a leading export commodity for Africa with an annual export value of $\$ 2.7$ billion (U.S.). Fish is one of the cheapest sources of animal protein and accounts for $22 \%$ of the protein in sub-Sahara Africa and $40 \%$ of animal protein consumption in Nigeria (FDF, 2009). In 2013, fishery sector accounted for about $4 \%$ of the GDP and also contributed to $42 \%$ in agricultures to national GDP (FDF, 2013). In Nigeria, fish demand as estimated by Ruma (2008) was 2.1 million metric tons at $11.5 \mathrm{~kg}$ per capita consumption and going by 2013 estimates, fish demand stands at 2.66 million MT while local supply is 0.76 million MT with a per caput consumption of $15.46 \mathrm{~kg}$.the statistics for fish supply provided by the Federal Department of Fisheries(FDF) revealed that the average domestic annual fish supply has never met the demand. Nevertheless, such yearly occurring deficits have been offset through enormous imports by various governments. The negative effects of these imports on the nation's foreign reserve have been variously acknowledged (FAO, 2002; FAO, 2006). However, it's obvious that fish supply from marine and freshwater capture fisheries cannot meet the growing global demand for aquatic production. This together with national efforts aimed at generating foreign currency and higher standard of living have focused the attention of many countries on the development and strengthening aquaculture (Rana et al., 1997). Irrespective of the increase in fish production, the nutritional requirement from the average protein intake in developing countries is still relatively unattained. Hence, this paper attempts to: describe the socioeconomic characteristics of the fish farmers, identify the types and nature of fish farming practices in the area, examine the costs and returns relationship of fish farming and investigate the variables that are likely to influence fish output. The remainders of the paper were organized as follows. The theoretical basis on which the paper is anchored was discussed followed by methodological and analytical frameworks. Next is the results and discussion of findings followed by conclusion and policy recommendations.

E. O. Edet, Department of Agricultural Economics, University of Calabar, Calabar, Cross River State, Nigeria.

P. O. Udoe, Department of Agricultural Economics, University of Calabar, Calabar, Cross River State, Nigeria.

E. D. Uwah, Department of Agricultural Economics, University of Calabar, Calabar, Cross River State, Nigeria. 
Some theoretical issues

The theories relevant to this study are the theories of production and cost functions. Production function relates output $(Q)$ to input variables $\left(X_{1}, X_{2}\right)$ (see Quandt, 1958) that is:

$Q=F\left(X_{1}, X_{2}\right)$

From equ(1), the total productivity of $X_{1}$ in the production of $Q$ can be secured from the input of $X_{1}$ if $X_{2}$ is assigned the fixed value $\mathrm{X}_{2}^{0}$ :

$Q=F\left(X_{1}, X_{2}^{0}\right)$

The input level $X_{2}{ }^{0}$ is treated as a parameter, and $Q$ becomes a function of $X_{1}$ alone. The relation between $Q$ and $X_{1}$ may be altered by changing $X_{2}^{0}$.

For the cost function, if the entrepreneur purchases $X_{1}$ and $X_{2}$ in perfectly competitive markets at constant unit prices, the entrepreneur total cost of production (c) is established thus:

$C=r_{1} x_{1}+r_{2} x_{2}+b$

Where $r_{1}$ and $r_{2}$ are the respective prices of $x_{1}$ and $x_{2}$, and $b$ is the cost of the fixed inputs and the input combinations purchased for specified total cost becomes:

$C^{0}=r_{1} x_{1}+r_{2} x_{2}+b$

Where $\mathrm{C}^{0}$ is a parameter and solving equ (4) for $\mathrm{x}_{1}$ becomes:

$x 1=\frac{a 0-b}{r 1}-\frac{r^{2}}{r 1}, x_{2}$

For the entrepreneur to make the revenue, he sells his output at a fixed price, which is a function of the output $(\mathrm{Q})$.Therefore, its profit function becomes:

$\pi=P Q-\Phi(Q)-b$

Therefore to maximize profit, $\pi$, set its derivative with respect to $Q$ equal to zero is given by:

$\frac{\partial \pi}{\partial Q}=P-\Phi 1(Q)=0$

And moving the $\mathrm{MC}$ to the right becomes:

$P=\Phi^{1}(Q)$

From the above sets of equations, the entrepreneur must equate the $\mathrm{MC}$ (marginal cost) with the constant selling price of his output. Note that he can increase his profit $(\pi)$ by expanding his output if the addition to his revenue $(p)$ of selling another unit exceeds the addition to his cost (MC).

\section{METHODOLOGY}

\section{Description of the study area}

The study was conducted in Calabar metropolis, Cross River State (CRS), Nigeria. The area is situated in the Southern geopolitical zone of the state which comprises of Calabar Municipality and Calabar South, Calabar Metropolis lies between latitudes ${\mathrm{N} 04^{0}}^{\circ} 56^{\prime} 00^{\prime \prime}$ and $\mathrm{N}^{\circ} 5^{\circ} 40^{\prime} 0^{\prime \prime}$ North of the Equator and longitudes E08 $8^{\circ} 18^{\prime} 40^{\prime \prime}$ and E08 $24^{\prime} 0^{\prime \prime}$ of the Meridian. The town is flanked on its eastern and western borders by two large perennial streams viz: the Great Kwa River and the Calabar River respectively. It has an area of $406 \mathrm{~km}^{2}$ and a population of 371,022 (NPC, 2006). The metropolis has two clear identifiable seasons; the rainy or wet season that last from April to October and dry season from November to March (Antigha, 2014). Calabar averages just less than $3,000 \mathrm{~mm}$ of precipitate annually. Temperature is relatively constant throughout the course of the year, with average high temperatures usually ranging from 25 to 28 degrees Celsius. The major occupation of the people is farming (fish farms inclusive) and major crops cultivated include cassava, yams, rice, plantain, banana, cocoyam, maize, cocoa, rubber, and groundnut while major livestock are poultry, pigs, sheep and cattle (Agbor, 2007). Understandably, fish farms flourish in the area because of the favourable environmental features and adaptable to the business in spite of rigidities in terms of cost of feeds and funds from financial institutions. 


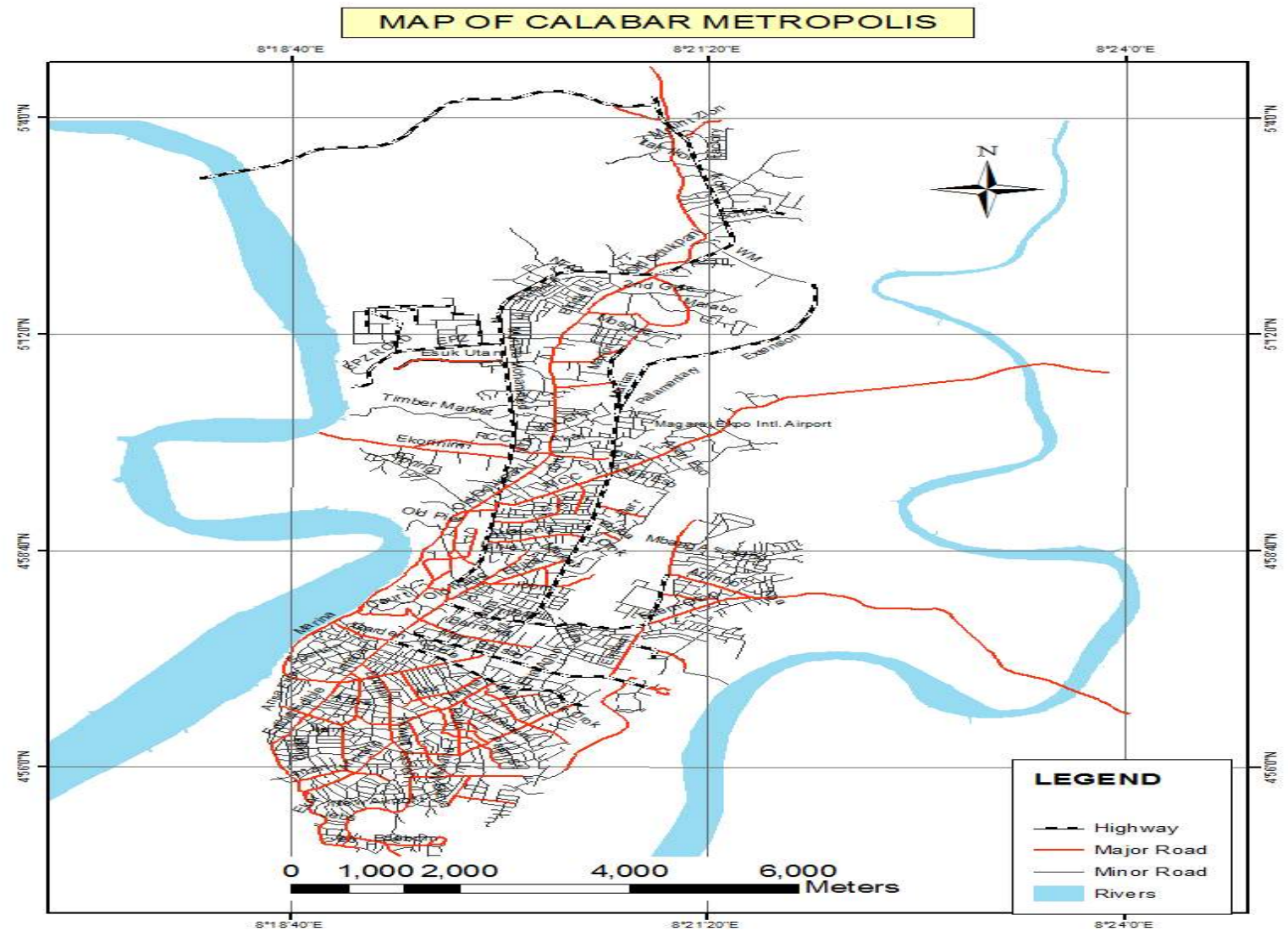

Fig. 1: Map Showing the Study Area

Source: Geographic Information System (GIS) Laboratory, Department of Geography and Environmental Science, University of Calabar.

\section{Sampling procedure and sampling size}

A two-stage sampling procedure was employed in selecting respondents for this study. In the first stage, 20 fish farmers from each of the two Local Government Areas (LGAs - Calabar municipality and Calabar south) was purposively selected, giving a total of 40 fish farmers, based on the availability of large number of fish farms. In the second stage, 15 fish farmers were randomly selected from the two LGAs giving a total of 30 fish farmers, representative of the LGAs, which were used for the study. Thus, a total of 30 farmers were used for analysis.

\section{Sources of data and method of collection}

Data for the analysis was obtained through primary sources. Primary data were elicited through the use of questionnaire which was supplemented with oral discussion. The questionnaire was designed based on the study objectives and divided into two main sections. Section one elicit information on the personal characteristics of the respondents, while section two elicit responses to address the research questions and objectives.

\section{Analytical technique}

Descriptive, inferential and budgetary technique was used to analyze the data. Descriptive statistic such as tables, frequency and percentages was used to examine objectives 1 and 2. Objective 3 was analyzed using budgetary techniques analysis such as gross margin. This will enable the estimation of the total costs cum total revenue accrued to the enterprise within a specific production period. The difference between revenue (returns) and Total Variable Cost (TVC) makes up the Gross Margin (GM). 
where:

$\mathrm{GM}=$ Gross Margin

$\mathrm{TR}=$ Total Revenue

$\mathrm{TVC}=$ Total Variable Cost

Net Farm Income $=$ TR - TC

Objective 4 was analyzed using the ordinary least square method (koutsoyiannis, 1977). The semi-log production function was chosen as the lead equation. Gujarati and Sangeetha (2007) gave the implicit model as:

$$
Y=b_{0}+b_{1} \log X_{1}+b_{2} \log X_{2}+b_{3} \log X_{3}+b_{4} \log X_{4}+b_{5} \log X_{5}+b_{6} \log X_{6}+b_{7} \log X_{7}+U
$$

For this study, the implicit function was estimated using variables influencing fish farming in the study area as follows:

$\log Q O F P=b_{0}+b_{1} \log A G+b_{2} \log E D U+b_{3} \log F E+b_{4} \log S D+b_{5} \log L B+b_{6} \log C F+b_{7} \log P S+U$

where:

QOFP = Quantity of fish produce in Kilograms

$A G=$ Age (years) $\left(b_{1}>0\right)$

$\mathrm{EDU}=$ Education (No. of years in school) $\left(\mathrm{b}_{2}>0\right)$

$\mathrm{FE}=$ Farming experience (years) $\left(\mathrm{b}_{3}>0\right)$

$\mathrm{SD}=$ Stocking density (number of fish per pond size) $\left(\mathrm{b}_{4}<0\right)$

$\mathrm{LB}=$ Labour (Mandays)(indeterminate)

$\mathrm{CF}=$ Cost of feed $\left(\mathrm{b}_{6}>0\right)$

$\mathrm{PS}=$ Production system $\left(\mathrm{b}_{7}>0\right)$

$\mathrm{U}=$ Error term

Note that $b_{1}$ to $b_{7}$ parenthesis are a priori expectations

\section{RESULTS AND DISCUSSION}

Table 1 shows the distribution of fish farmers with respect to their socio-economic characteristic. The results revealed that male $(70 \%)$ are actively engaged in fish farming than the female $(30 \%)$. This result can be justified by the assertion of Brummett, et al. (2010) that fisheries activities are mostly dominated by men. Majority $(33.3 \%)$ of the fish farmers fall within the age bracket of $40-49$ years, 26.7 percent fall within $30-39$ years, $23.3 \%$ fall within $50-59$ of age while $16.7 \%$ fell within the age range of 60 and above. This age bracket is a productive age which portends better future for fish production also it is considered as economically active age (Olowosegun et al., 2004). This indicates that very few old people are involved in fish farming. This result is in line with the findings of Oluwawumi et.al. (2010). it was also discovered that majority of the farmers were married $(60 \%)$ while very few were widowed and separated. These results show that marriage confer some level of responsibility and commitment on individual who are on it (Fakoya, 2000; Oladoja et. al., 2008). Most fish farmers had a small household size 2$4(40 \%)$ due to the migration of some members of the household. All of the respondents were highly educated as all of them had attended tertiary education (100\%). This means that fish farming is a highly technical enterprise that requires learned farmers (Penda, et al., 2013). It also requires a lot of technical and scientific knowledge to be successfully undertaken. Assessing the primary occupational status of the respondent, majority of the fish farmers were civil servants $(50 \%)$, while others where trading $(6.7 \%)$, business owners $(2 \%)$,teaching $(3.3 \%)$ and only $10.0 \%$ engage in fish farming. This finding corroborates with what Ideba et al. (2013) and Adewuyi et al. (2010) alluded that $100 \%$ and $79 \%$ respectively of fish farmers were not on full time basis. The study also revealed that $56.7 \%$ of the sampled respondents were the most experienced in fish farming community. This result is consistent with what Olaoye et. al. (2013) opined that respondents with the highest number of years of experience perhaps have good skills and better approaches to fish farming business. The study also posits that the respondents with comparatively longer years of experience were able to forecast market situation in which they sell their products at higher prices. Those with less years of experience, faces many risks in the early stage of their fish farming business. 
Table 1: Socio-economic characteristics of fish farmers in the study area

\begin{tabular}{|c|c|c|}
\hline Variable & Frequency & Percentage \\
\hline \multicolumn{3}{|l|}{ Gender } \\
\hline Male & 21 & 70 \\
\hline \multirow[t]{2}{*}{ Female } & 9 & 30 \\
\hline & 30 & 100 \\
\hline \multicolumn{3}{|l|}{ Age(years) } \\
\hline $30-39$ & 8 & 26.7 \\
\hline $40-49$ & 10 & 33.3 \\
\hline $50-59$ & 7 & 23.3 \\
\hline \multirow[t]{2}{*}{60 and above } & 5 & 16.7 \\
\hline & 30 & 100 \\
\hline \multicolumn{3}{|l|}{ Marital Status } \\
\hline Single & 10 & 33.3 \\
\hline Married & 18 & 60.0 \\
\hline Divorced & 1 & 3.3 \\
\hline \multirow{2}{*}{ Widow(er) } & 1 & 3.1 \\
\hline & 30 & 100 \\
\hline \multicolumn{3}{|l|}{ Household size } \\
\hline$>2$ & 8 & 26.7 \\
\hline $2-4$ & 12 & 40.0 \\
\hline $5-7$ & 6 & 20.0 \\
\hline \multirow[t]{2}{*}{8 and above } & 4 & 13.3 \\
\hline & 30 & 100 \\
\hline \multicolumn{3}{|l|}{ Education level } \\
\hline No formal education & 0 & 0 \\
\hline Primary Education & 0 & 0 \\
\hline Secondary Education & 0 & 0 \\
\hline NCE/OND & 5 & 16.7 \\
\hline \multirow{2}{*}{ University } & 25 & 83.3 \\
\hline & 30 & 100 \\
\hline \multicolumn{3}{|l|}{ Primary Occupation } \\
\hline Civil Servants & 18 & 60.0 \\
\hline Trading & 2 & 6.7 \\
\hline Fish Farming & 3 & 10.0 \\
\hline Business & 2 & 6.7 \\
\hline Teaching & 1 & 3.3 \\
\hline \multirow[t]{2}{*}{ Others } & 4 & 13.3 \\
\hline & 30 & 100 \\
\hline \multicolumn{3}{|l|}{ Years of Experience } \\
\hline$<1$ & 3 & 10.0 \\
\hline $1-3$ & 5 & 16.7 \\
\hline $4-6$ & 5 & 16.7 \\
\hline \multirow[t]{2}{*}{7 and above } & 17 & 56.7 \\
\hline & 30 & 100 \\
\hline
\end{tabular}

Source: Field Survey (2017)

Table 2 indicates the socio-economic characteristics of fish farmers in the area of study. The survey shows that all the respondents in the study area used intensive system of farming. This is because the prime motive of farmers is to make profit. This is in line with the findings of Olaoye et.al. (2013). The collapsible pond also known as mobile pond $(46.7 \%)$ and concrete ponds $(43.3 \%)$ were mostly preferred by the fish farmers. This was because concrete pond has the advantage of lasting over ten years and is not affected by climatic changes (i.e. not drying up during the dry season when the water table is low). This result, however, disagrees with the findings of Ideba et al. (2013) who stated that earthen pond/production system was mostly preferred in fish farming (aquaculture). The number of operational ponds per individual farmer was mostly on small size less than 5 ponds $(53.4 \%), 33.3 \%$ of the farmers had between 5 10 ponds while just $13.3 \%$ had above 10 ponds. Sources and quantity of water availability are one of the most important factors to be considered when selecting a site for aquaculture practice. Most (86.7\%) of the respondents had borehole as their major source of water, $10 \%$ depend on deep well, while $3.3 \%$ depend on stream as source of water for the enterprise. Based on the types of fish stocked, majority (43.3\%) of the fish farmers stocked Clarias (Catfish), a fast maturing species of catfish, followed by poly-culture (Clarias and Tilapia)(30\%), 20\% stocked Heterobranchus with a few 
$6.7 \%$ tilapia (Lady fish). This result was in line with Olayode et al.(2013) and Emmanuel et al (2014). Catfish was mostly preferred in the study area because of its good taste, fast physiological maturity and gives higher reproductive capacity in ponds, greater demand preferences and high feed conversion ratio. Majority $(86.7 \%)$ of the farmers stocked between $41-60$ fish per pond followed by $13.3 \%$ of the farmers who stock between $20-40$ fish per pond. The results also indicated that most fish feeds used by the farmers are formulated $(70 \%)$ which is very expensive to purchase. However, only $30 \%$ of the farmers used locally-made feeds. This locally-made feeds contain substandard nutrient value owing to paucity of active ingredients in such feeds. Thus, such feeds may contribute to high mortality and morbidity rates in most fish farmers in the area (Ideba et al., 2013).

Table 2: Surveyed results of fish farmers in the study area

\begin{tabular}{|c|c|c|}
\hline Variable & Frequency & Percentage \\
\hline \multicolumn{3}{|l|}{ Type of Farm } \\
\hline Intensive & 30 & 100 \\
\hline Extensive & - & - \\
\hline Total & 30 & 100 \\
\hline \multicolumn{3}{|l|}{ Types of pond } \\
\hline Earthen & 2 & 6.7 \\
\hline Concrete & 13 & 43.3 \\
\hline Collapsible & 14 & 46.7 \\
\hline All of the above & 1 & 3.3 \\
\hline Total & 30 & 100 \\
\hline \multicolumn{3}{|l|}{$\begin{array}{l}\text { Number of pond/production } \\
\text { system }\end{array}$} \\
\hline$<5$ & 16 & 53.4 \\
\hline $5-10$ & 10 & 33.3 \\
\hline 10 and above & 4 & 13.3 \\
\hline Total & 30 & 100 \\
\hline \multicolumn{3}{|l|}{ Sources of water } \\
\hline Well & 3 & 10 \\
\hline Stream & 1 & 3.3 \\
\hline Borehole & 26 & 86.7 \\
\hline Total & 30 & 100 \\
\hline \multicolumn{3}{|l|}{ Type of fish stocked } \\
\hline Cat fish/Clarias & 13 & 43.3 \\
\hline Poly-culture (Clarias and Tilapia) & 9 & 30 \\
\hline Tilapia & 2 & 6.7 \\
\hline Heterobranchus & 6 & 20 \\
\hline Total & 30 & 100 \\
\hline \multicolumn{3}{|l|}{ Stocking density per pond } \\
\hline$<2000$ & 4 & 13.3 \\
\hline $2000-3000$ & 26 & 86.7 \\
\hline Total & 30 & 100 \\
\hline \multicolumn{3}{|l|}{ Source of feeds } \\
\hline Local feeds & 9 & 30 \\
\hline Formulated feeds & 21 & 70 \\
\hline Total & 30 & 100 \\
\hline
\end{tabular}

Source: Field Survey Data (2017)

Table 3 gives estimates of cost and returns analysis made from fish farming using cost (fixed and variable costs) and fish yield data generated by each of the sampled fish farmers per season. The cost and returns analysis in Table 3 revealed that the fixed cost accounted for the largest proportion (57.14\%) of the total cost of fish farming in the study area. This indicates that large amount of money spend by fish farmers in the study area was majorly for the construction of the pond. The cost of feed (34.29\%) from fingerlings to market weight accounted for the largest proportion of the operating cost. This finding is in agreement with Adewunmi et al. (2005). From the survey, a total cost (TC) of $\$ 525,000$ was incurred by a respondent per 
fishing cycle while total revenue (TR) of $\$ 650,000$ was realized with a returning gross margin (GM) of $\$ 425,000$ and a net farm income (NFI) of 125,000. This indicates that fish farming in the study area was profitable (see for instance, Ideba et al. ,2013; Olayoye et al.,2013; Ashaolu et al.,2006) whose results revealed that the business is profitable according to the level of investment and variable cost minimization.

Table 3: Estimate of cost and returns of fish farming based on 1000 fingerlings in the study area

\begin{tabular}{llc}
\hline Items & Amount(\#) & Total Cost (\%) \\
\hline A.VARIABLE COST & 180,000 & 34.29 \\
${ }^{++}$Feeds & 15,000 & 2.86 \\
Labour & 30,000 & 5.71 \\
${ }^{*}$ Fingerling & 225,000 &
\end{tabular}

B. FIXED COST

** Cost of constructing the pond $\quad 300,000$

TOTAL FIXED COST 300,000

TOTAL COST (A+B) $\quad 525,000$

TOTAL REVENUE $\quad 650,000$

GROSS MARGIN $\quad 425,000$

NET FARM INCOME $\quad 125,000$

Notes: *=per stocking cycle/period for 1000 fingerlings; cost of feed per $15 \mathrm{~kg}=\mathrm{N} 5800$; cost of fingerling=N30.00; sales per kilo=N650.00; ${ }^{* *}=$ Inclusive of labour, cement, chippings etc $;++=\mathrm{N} 180$ per feed to market weight.

Source: Field Survey Data (2017);
A multiple regression analysis was done in four functional forms (linear, semi-log, double log and exponential forms). Based on the statistical significance of the coefficients and the economic theory that support production concept, the semi-log production function was chosen as the lead equation. The semi-log was chosen also because it has the highest $R^{2}$ value (0.99) and F-ratio (311.28) (Table 4). Stocking density had a positive relationship with output and was significant at $1 \%$ thereby conforming to the a priori expectation. This result also agrees with the findings of Adewuyi, et al. (2010) and Nwosu and Onyeneke (2013). Production system was significant at $1 \%$ and had a positive relationship with output, meaning that the more efficient the production system used, the greater the output. The cost of feed used was significant at $1 \%$ and had a positive relationship with output. Education had a negative relationship with output and was significant at $5 \%$. This means that one can go into fish faring without formal education.

Table 4: Summary results showing factors that influence fish output in the area

\begin{tabular}{lllll}
\hline Variable & Linear & Double-log & Semi log* & Exponential \\
\hline Age & -0.582 & 0.152 & 0.123 & -0.110 \\
& $(0.462)$ & $(0.140)$ & $(0.165)$ & $(0.135)$ \\
Education & -0.020 & -0.161 & $-0.271^{* *}$ & $-0.024^{* *}$ \\
& $(0.293)$ & $(0.121)$ & $(0.142)$ & $(0.086)$ \\
Farm & 0.661 & -0.028 & -0.131 & 0.185 \\
Experience & $(0.561)$ & $(0.117)$ & $(0.138)$ & $(0.164)$ \\
Stocking Density & 0.003 & -0.025 & $2.050^{* * *}$ & -0.001 \\
& $(0.007)$ & $(-0.051)$ & $(0.070)$ & $(0.002)$ \\
Labour & 0.000 & -0.008 & 0.013 & $-3.163 \mathrm{E}-005$ \\
& $(0.0)$ & $(0.012)$ & $(0.014)$ & $(0.000)$ \\
Feed cost & $7.231 \mathrm{E}-006$ & -0.052 & $0.600^{* * *}$ & $-5.576 \mathrm{E}-005$ \\
& $(0.000)$ & $(0.085)$ & $(0.100)$ & $(0.000)$ \\
Production & 3.839 & $2.042^{* * *}$ & $8.399^{* * *}$ & 0.911 \\
System & $(0.319)$ & $(0.074)$ & $(0.087)$ & $(0.093)$ \\
Constant & -2.423 & 0.713 & -4.596 & -0.195 \\
& $(2.124)$ & $(0.078$ & $(1.033)$ & $(0.620)$ \\
$R^{2}$ & 0.930 & 0.988 & 0.999 & 0.904 \\
Adjusted $R^{2}$ & 0.907 & 0.985 & 0.999 & 0.873 \\
F-Ratio & $41.61^{* * *}$ & $265.31^{* * *}$ & $311.28^{* * *}$ & $29.427^{* * *}$ \\
S.E & 1.286 & 0.131 & 0.154 & 0.376 \\
DW & 1.68 & 2.03 & 1.855 & 1.64 \\
\hline
\end{tabular}

Notes: ${ }^{* * *}=$ significant at $1 \%$ level; ${ }^{* *}=$ significant at $10 \%$ level; DW= Durbin Watson. Values in parenthesis at standard are errors; + = Lead equation 
Table 5 shows the constraints faced by fish farmers. Majority (43.33\%) of the respondents interviewed complained of high cost of feed. This was in line with lke et al. (2003) who reported that high cost and unavailability of fish feed concentrate make fish farming unproductive. Lack of fund was complained by $16.66 \%$ of the farmers. Fund is vital in purchasing productive inputs and in payment of hired labour. About $23.33 \%$ of the respondent complained of lack of awareness and skilled personnel (see Table 5). This was largely responsible for the failed attempts to resuscitate the aquaculture business in the early 90 s by the then Federal Military Government of Nigeria.

Table 5: Some constraints encountered in fish farming enterprise in the area

\begin{tabular}{lcc}
\hline Constraints & No. of respondent & Percentage \\
\hline lack of awareness and skilled & 7 & 23.33 \\
personnel & 5 & 16.67 \\
Lack of funds & 2 & 6.67 \\
Predation & 3 & 10.00 \\
Water quality/availability & 13 & 43.33 \\
High cost of feed & $\mathbf{3 0}$ & $\mathbf{1 0 0}$ \\
Total & & \\
\hline
\end{tabular}

Source: Field Survey Data (2017)

\section{CONCLUSION AND POLICY RECOMMENDATIONS}

Stocking density, production system, feed cost and education were found to significantly influence fish output in the study area. The total revenue realized from total cost of production of $\$ 525,000$, was $\$ 650,000$, making a net farm income of 125,000 . It was, therefore, concluded that fish farming in the area was highly profitable as revenue generated adequately covered the operating expenses and a reasonable floating capital left. A vast majority of the fish farmers indicated that, they were faced with problems of high cost of feeds, lack of awareness and skilled personnel, water quality/availability and lack of capital. Based on the findings, the following policy recommendations were made:

I. Extension services in the state should be updated via regular organization and workshops for the benefit of fish farmers in the area;

II. Nutrition feed research institute should be establish to helps reduce the cost of feeds and enhance the capacity of fish farmers nationwide;

III. Local nutritive feeds should be made readily available in the markets as this will help in the long run to reduce the demand and cost of foreign feeds.

IV. Government and financial institutions should encourage fish farmers by making loans readily available to them at zero or reduced interest rates. This policy will encourage fish farmers to expand their enterprises and capacity for enhanced productivity of the commodity.

\section{REFERENCES}

Adewumi, M. O., Ayinde, O. E., Oladeinde, O. A. and Muhammed-Lawal, A., 2005. Economic Analysis of fish farming in Ogun state. In $19^{\text {th }}$ Annual Conference of the fisheries society of Nigeria (FISON), pp.572-577.
Adewuyi, S. A., Phillip, B. B., Ayinde, I. A. and Akerele, D., 2010. Analysis of profitability of fish farming in Ogun State, Nigeria. J Hum Ecol 31(3): 179-184.

Agor, G., 2007. The economics of population growth and changes in demographic structure. In MOFINEWS. Cross River State privation exercise- journey so far. Jan-Feb, 2007. 6 (3): 7.

Antigha, R. E. E., 2014. Analytical Modelling of RainfallRunoff for Calabar Metropolis, Cross River State, Nigeria: PhD Dissertation (in press), Dept. of Agric \&Environmental Engineering, Rivers State University of Science \& Technology, Port Harcourt, Nigeria,

Ashaolu, F. O., Akinyemi, A. A. and Nzekwe, L. S., 2006. Economic Viability of homestead Fish Production in Abeokuta Metropolis of Ogun State, Nigeria. Asset Series A, 6(2): 209-220.

Brummett, R. E., Youaleu, J. L. Tiani, N. A and Kenmegne, M., 2010. Women's traditional fishery and alternative aquatic resource livelihood strategies in the southers Cameroonian Rainforest. Fisheries Management and Ecology 17:221 230.

Ele, I. E., Ibok, O. W., Antia-Obong, E. A., Okon, I. E and Udoh, E. S., 2013. Economic Analysis of Fish Farming in Calabar, Cross River State, Nigeria. Greener Journal of Agricultural Sciences, Vol. 3(7), pp. 542-549.

Emmanuel, O., Chineye, A., Oluwatobi, A. and Peter, k., 2014. Review Of Aquaculture Production and Management in Nigeria. America Journal of Experimental Agriculture, 4(10).

Fakoya, E. O., 2000. Farmers Use of Sustainable Land Management Practices in Ondo State, Nigeria. Unpublished $\mathrm{PhD}$. Thesis, Department of 
Agricultural Extension and Rural Development, University of Ibadan. Pp 160.

FAO., 2002. Fisheries statistics capture production, FAO, Rome, Italy 92(1):627.

FAO., 2006. Fisheries Technical Paper No. 407. Rome RAO, pp. 149.

Federal Department of Fisheries., 2009. Nigeria National Aquaculture strategy. Assisted by FAO formally approved by Government.p.18.

Federal Department of Fisheries., 2013. Fisheries Statistics of Nigeria Projected human population; fish demand and supply in Nigeria from $2000-2015$.

Greenfacts., 2004. World fisheries production. www.greenfacts.org/fisheries/o4-utilization.htm, retrieved on January 15, 2006.

Gujarati, D. N. and Sangeetha., 2007. Basic Econometrics. Tata McGraw Hill publishing company Ltd, New Delhi.

Ike, S. E., Onyishi, G. C., Ukwuaba, G. C and Oluason, V. A., 2009. Farm evaluation of profitability and farmer's acceptability of Bambara Nut waste as major protein supplement in fish diet in hetrobranchus and tilapia spp polyculture. Proceedings of National Farming System Research Network held at Umudike. Pp 127-129

Koutsoyiannis, A., 1977. Theory of Econometrics: An Introductory method. (2nd ed). London Macmillan press Ltd.

National Population Commission (N.P.C)., 2006. National Population Census 2006 Provisional Results, Abuja, Nigeria.

New Partnership for African Development, (NEPAD)., 2005. Action plan for the development of African fisheries and aquaculture. Report of NEPAD Fish for All Summit, Abuja.

Nwosu, C. S and Onyeneke, R. U., 2013. Effect of Productive Inputs of Pond Fish Production on the Output of Fish in Owerri Agricultural Zone of Imo State, Global Advanced Research Journals, Vol. 2(1) pp. 023-028.
Oladoja, M. A., Adedoyin, S. E. and Adeokun, O. A.,

2008. Training needs of fisher folks on fishing technologies. Journal of Food Agriculture and Environment Science and Technology. Vol. 6: No. 1 WFL publisher, Jelsinki, Finland www.worldfood.net.

Olaoye, O. J., Ashley-Dejo, S. S., Fakoya, E. O., Ikeweinwe, N. B., Alegbeleye, W. O., Ashaolu, F. O and Adelaja, O. A., 2013. Assessment ofSocio-Economic Analysis of Fish Farming in Oyo State, Nigeria.

Olawunmi, A. T., Dipeolu, A. O and Bamiro, O. M., 2010. Economic Analysis of Homestead Fish Production in Ogun State, J. Hum Ecol, 31(1):13-17.

Olowosegun, T., Sanni, A. O., Sule, A. M. and Bwala, R.

L., 2004. Contribution of Women to Fisheries development in Kainji Lake Basin, in 2004 FISON Conference proceedings, Pp 91-97.

Penta, S. T., Unaji, G. P. and Odeoemenem, I. U., 2013. Profitability analysis of fish Production from Concrete pond system in Benue State. International Journal of Research in social science. vol.2.No.4.

Quandt, H., 1958. Micro-economic theory: A Mathematical Approach. $2^{\text {nd }}$ edition McGrawHill kogakusha Limited. Library of Congress catalog card number 72-140956.

Rana, K., 1997. Recent trends in global apiculture production, $1985-1995$.

Ruma, Y. A., 2008. Fish production systems. A workshop held at Enugu State University, fisheries project. 